\title{
Organising the Radical Maritime Transport Workers
}

Maritime workers constituted a multi-faceted group, e.g. the seamen and stokers of many nationalities hired on the various national merchant fleets as well as the dockers and stevedores working in the harbours. Working conditions both on board and on land were tough and worsened due to the economic depression from the late 1920s onwards. The organisation of seamen in trade unions, especially, was a challenge as union activity was mainly land-based while seamen worked on ships that seldom called at their homeports. In addition, seamen were for long regarded as an unruly, individualistic and internationalist group who had few interests in organised union activities. Socialist party and labour leaders regarded the waterfront as a secondary field of work in sheer numbers, the maritime workers constituted but a small portion of the work force. ${ }^{1}$ Also, as Peter Cole and David Featherstone have underlined, apart from the 1913-established Marine Transport Workers' Industrial Union, the official maritime labour unions in the USA, Britain and elsewhere where preominantly exclusionary and segregationist. ${ }^{2}$ It comes therefore as no surprise that many of the leading figures in the radical waterfront both in Europe and the Americas had a background in the 'revolutionary industrial unionism' and the radical international syndicalism of the 'Wobblies', the Industrial Workers of the World, before and during the Great War. ${ }^{3} \mathrm{~A}$ further challenge were the unemployed seamen living ashore. Especially during the 1920s and 1930s, they constituted a problematic group for the existing socialist-led maritime labour unions: receptive for radical, i.e., communist, agitation and propaganda, they could turn into a 'fifth column' at union meetings and push for a politicisation of trade union activities.

1 See further Ludwig Eiber, Arbeiter und Arbeiterbewegung in der Hansestadt Hamburg in den Jahren 1929 bis 1939. Werftarbeiter, Hafenarbeiter und Seeleute: Konformität, Opposition, Widerstand (Frankfurt am Main: Peter Lang, 200o); Dieter Nelles, Widerstand und internationale Solidarität. Die Internationale Transportarbeiter-Föderation (ITF) im Widerstand gegen den Nationalsozialismus (Essen: Klartext-Verlag, 2001).

2 Peter Cole, Wobblies on the Waterfront: Interracial Unionism in Progressive-Era Philadelphia (Urbana: University of Illinois Press, 2007); David Featherstone, Resistance, Space and Political Identities: The Making of Counter-Global Networks (Chichester: Wiley-Blackwell, 2008).

3 See further Peter Cole, David Struthers and Kenyon Zimmer (eds.), Wobblies of the World. A Global History of the IWW (London: Pluto Books, 2017). 


\section{A Communist Answer to a Syndicalist Initiative}

The initial idea of establishing a radical umbrella organisation or a red Seamen's International was raised by syndicalist activists in Latin America in the aftermath of the Great War. According to Rainer Tosstorff, its main protagonist was Tom Barker, the representative of the Argentinian anachist labour association Federación Obrera Regional Argentina or FORA-V Congress at the founding congress of the RILU in Moscow in July 1921. Barker, born in 1887 in England, had emigrated to New Zealand in 1911 where he joined the Industrial Workers of the World or IWw in 1913, and had made headlines as a colourful union and anti-war activist in Australia until 1918 when the authorities expelled him. He ended up in Latin America and became an organiser of maritime workers in Chile and Argentina. On his way to Soviet Russia, he attended a conference in Berlin in December 1920. ${ }^{4}$ This conference had been summoned by syndicalist organisations to discuss the call by the International Trade Union Council (ITUC) for an international trade-union congress to meet in Moscow in $1921 .^{5}$

The 1920 Berlin Conference generated a rupture within the syndicalist movement. While most of the syndicalist organisations, including the IWw and the British Shop Stewards' Movement, decided to send delegations to Moscow, the German syndicalist trade union Freie Arbeiter Union Deutschlands (Free Workers' Union of Germany, FAUD) declined to do so as it opposed the communists idea of subordinating the unions to party control. However, some member organisations of the FAUD contested the decision, among others the syndicalist Deutscher Schiffahrtsbund or German Maritime Union which decided to send a delegation to Moscow. The Schiffahrtsbund had been set up during the turmoils at the end of the war. It soon emerged as an organisation for radical seamen and constituted a serious competitor to the ADGB-afiliated and socialist-controlled Transport Workers' Union. ${ }^{6}$

It is tempting to assume that Barker might have raised idea for a red Seamen's International in informal discussions at the Berlin Conference, perhaps with George Hardy who was the representative of the Iww at the conference. Interestingly, Barker, Hardy and Jack Tanner, the representative of the British Shop Steward's Movement, stood out at the conference as supporters of centralism and were in favour of co-operation with Moscow. According to Tosstorff, Barker claimed at his arrival in Moscow that the initiative to call

\footnotetext{
4 "Tom Barker," in Lazar Jeiferts, Amèrica Latina en la International Communista 1919-1943, online available at https://books.openedition.org/ariadnaediciones/955 (checked 28.1.2020).

5 Tosstorff, The Red International of Labour Unions, 345.

6 Tosstorff, The Red International of Labour Unions, 242-248.
} 
for an international seamen's congress had been initiated among maritime transport workers in Argentina and Uruguay and had met with agreement from syndicalist organisations in Europe. This was at least the case with the Schiffahrtsbund who discussed its international orientation at a conference held in Stettin in January 1921. It is likely that Barker participated at the Stettin Conference as he moved from Germany to Soviet Russia in February 1921. ${ }^{7}$

On top of the agenda of the 1921 Stettin Conference was the relationship between the Schiffahrtsbund and the International Seafarers' Federation (ISF). The latter organisation had been established in 1918 in opposition to the (then defunct) ITF and was dominated by J. Havelock Wilson, the notorious leader of the British National Sailors' and Firemen's Union (NSFU) and member of the extreme right wing of the British Trades Unions Congress TUC. As an outcome of the conference, the Schiffahrtsbund declined to join the ISF. Instead, the conference backed the idea of establishing a revolutionary Seamen's International as a radical opposition to the ISF. At this point, the doors were still left open towards the ITF as the organisation was in a process of re-organisation after it had been re-established in 1919; the Schiffahrtsbund was not a member of the ITF. ${ }^{8}$

Shortly after his arrival in Moscow in February 1921, Barker raised the idea of a red International for seamen with ITUC General Secretary Mikhail Pavlovich Tomsky. The latter initially supported it and Baker organised a wider meeting in late April where it was decided to summon an international congress of maritime workers in Petrograd in August 1921. ${ }^{9}$ On top of the agenda of the projected seamen's congress was the establishment of a red Seamen's International. The envisioned red Seamen's International was to have a dual role. Apart from its legal activities to counteract the influence of the ISF, the red Seamen's International was to set up a secret organisation for the transportation of people, literature and information to all parts of the world. ${ }^{10}$

Barker left Moscow after the meeting and moved to Britian where he made propaganda for the forthcoming seamen's congress. He therefore was absent from the scene in Moscow in May and June when the International Trade Union Council reconsidered its earlier positive stance towards the seamen's congress and turned against the idea of launching a red Seamen's International. Instead,

7 Tosstorff, The Red International of Labour Unions, 345.

8 Tosstorff, The Red International of Labour Unions, 261-262.

9 Tosstorff, The Red International of Labour Unions, 345.

10 Report of the meeting of the Provisional Council concerned with the organisation of a Red International of Water Transport Workers' Unions, held in Moscow, Hotel Lux, 28.4.1921, 534/5/149, 11, RGASPI. 
the International Trade Union Council decided to establish a new body, the International Propaganda Committee for Transport Workers or IPC-TW, and to relocate the seamen's congress to Moscow. In addition, the seamen's congress was downgraded to the level of a mere conference and the projected seamen's organisation was to be amalgamated with the IPC-TW. Not surprisingly, the proposition of the International Trade Union Council was fiercly criticised by it syndicalist members. ${ }^{11}$

All in vain. The final chapter in the syndicalist initiative to establish a red Seamen's International opened with the joint conference of the seamen and the representatives of the IPC-TW and RILU in mid-August 1921. Alexander Lozovsky, Secretary General of the newly founded Red International of Labour Unions or RILU, declared that he was not in favour of challening the International Trade Secretariats by creating red internationals. The representatives of the Schiffahrtsbund and the communist-dominated German General Workers' Union (Allgemeine Arbeiter-Union), in turn, presented a modified plan and suggested the establishment of a red seamen's union as part of the IPC-TW with operational units, or so-called Port Bureaus, in the biggest ports of the world. The RILU representatives contested by proposing to broaden the leadership and scope of IPC-TW. Not surprisingly, the RILU poposition was accepted with 10 votes against 5 of the syndicalist delegates, including Barker. On 15 August, the RILU Executive Board proceeded to put these decisions into effect. A bureau for communications and information was to be set up within the IPC-TW in order to prepare the establishment of Port Bureaus. Three representatives for the seamen were added to the leadership of the IPC-TW: Tom Barker, the Australian William Casey and the Russian Grigorii (Gregory) Palvovich Achkanov. ${ }^{12}$

The newly founded International Propaganda Committee for Transport Workers had two main objectives for its work on the waterfront. The first aim was to create cells among ship crews and among harbour workers. These units were to constitute themselves as the revolutionary vanguard within the local sections of the national unions for seamen and harbour workers, and were to constitute themselves as the so-called revolutionary opposition within the national unions. The cells were to serve as core action units in case of a strike or other legal activity while the revolutionary opposition was to maintain regular communications with the representative of the IPC-TW in the country. The IPC-TW, in turn, was to produce and publish the material for propaganda

\footnotetext{
11 Tosstorff, The Red International of Labour Unions, 346, 416.

12 Tosstorff, The Red International of Labour Unions, 417-418.
} 
and agitation among maritime transport workers, such as manifestos and pamphlets. $^{13}$

The second task of the IPC-TW was the establishment of so-called Port Bureaus in chief ports in the world. The key task of the Port Bureaus was to serve as liaison centre for communication and information between the headquarters of the IPC-TW and the national sections of the revolutionary opposition. Paralell to its legal activities, a Port Bureau was expected to engage in illegal work and clandestine operations. ${ }^{14}$

Initially, Port Bureaus were envisioned in locations where legal communist activites was possible, namely New York, San Francisco, Sydney, Liverpool, Hamburg, Buenos Aires and Marseille. Material produced by the International Propaganda Committee or the individual Port Bureaus was to be distributed to the other units in the network. For example, the projected Port Bureaus in Hamburg and Liverpool were given the task to publish material in Norwegian in order to reach out to Norwegian seamen. This comes at no surprise as the Nowegian merchant fleet ranked among the largest in the world. However, agitation and propaganda work among Norwegian seamen was hardly effective in Norway as the ships rarely called at their home ports but spent long periods abroad. Consequently, the Norwegian Seamen's and Stokers' Union (Norsk Matros- og Fyrbøter-Union) had established sections in Liverpool and Hamburg and the IPC-TW aspired to infiltrate them and use them for its propaganda work. ${ }^{15}$

The establishment of Port Bureaus in Petrograd and Odessa during autumn 1921 set the stage for focussed communist agitation and propaganda among seamen. Attached to Port Bureaus were so-called International Seamen's Clubs or Interclubs for foreign seamen. Aiming for a global outreach, the IPC-TW also sent emissaries to Constantinople, London and Liverpool to investigate the possibility of starting work in these port cities. ${ }^{16}$ In addition, the IPC-TW sent Jim Quinton to Hamburg to supervise the activities of the Schiffahrtsbund. Quinton's work was challenging as the syndicalist members of the Schiffahrtsbund were unfavourably disposed towards decisions made in Moscow and contested the affiliation of the Schiffahrtsbund with the ITF,

13 The Most Urgent Tasks of the International Committee of Propaganda of the Transport Workers (no date [ca. 1921], 534/5/149, 61-63, RGASPI.

14 The Most Urgent Tasks of the International Committee of Propaganda of the Transport Workers (no date [ca. 1921], 534/5/149, 61-63, RGASPI.

15 Tom Barker, Proposition for Marine TransPort Bureaus (no date [ca. 1921]), 534/5/149, 9697, RGASPI.

16 To the bureau members of the ITC-TW, no date [ca. 1921], 534/5/150, 9-10, RGASPI. 
a demand enacted by the RILU. However, Quinton found an ally in Albert Walter, a former syndicalist mariner who had joined the German Independent Social Democratic Party (USPD) in 1919. In contrast to the other leaders of the Schiffahrtsbund, Walter backed the RILU demand. Most importantly, Walter supported the idea of establishing a ships and harbour committee, i.e., the forerunner of a Port Bureau, in Hamburg that would include representatives of all nationalities calling at the port. ${ }^{17}$

Albert Walter's co-operation was crucial for gaining a successful start in Hamburg. Quinton informed the IPC-TW headquarters in Moscow that Walter was "the Communist within the Schiffahrtsbund" with a large amount of knowledge about the organisation of British maritime transport workers as he had previously served for nine months as representative of the British NSFU and had gained practival experience on working with national and foreign ship crews. ${ }^{18}$ However, this was of little help as the Schiffahrtbund protracted the establishment of a Port Bureau in Hamburg and by the end of the year, the representative of the RILU Bureau in Berlin instructed Quinton to speed up activities in Hamburg. ${ }^{19}$ Neither had there been much progress in other countries. Consequently, the IPC-TW headquarters issued a circular to its representatives in Britain, France, Germany, the Netherlands and the USA reminding them about the decision to establish Port Bureaus in their respective countries. ${ }^{20}$

\section{$2 \quad$ A Push towards the West}

The grandiose plan of the International Propaganda Committee for Transport Workers for opening operative units in all major ports across the world was slow to materialise. While the Bolsheviks established Port Bureaus in Vladivostok and Archangelsk in 1922, activities outside Soviet Russia had come to a deadlock. Apart from the Schiffahrtsbund and the British Shop Stewards' Movement, renamed in 1921 as the National Workers' Committee Movement, relations with syndicalist unions turned sour. ${ }^{21}$ In December 1921, the IWW

17 Jim Quinton to Deutscher Schiffahrtsbund Hamburg, letter dated 14.11.1921, 534/5/150, 1113, RGASPI.

18 [Jim Quinton] to 'Dear Comrade Hyen', Hamburg [?].11.1921, 534/5/150, 24-25, RGASPI.

19 Letter to 'Genosse Farwig', Berlin 26.12.1921, 534/5/150, 30-31, RGASPI. Farwig was the representative of the IPC-TW in Berlin and it is likely that the author of the letter was someone at the RILU Bureau in Berlin. The RILU had established an office in Berlin, the Middle or Central European Bureau (MEB), in 1920.

20 Circular letter in English, French and German by the IPC-TW, 534/5/150, 35-37, RGASPI.

21 Tosstorff, The Red International of Labour Unions, 249-252. 
officially cut its ties with Moscow and the RILU. ${ }^{22}$ In March 1922, the IWW expelled George Hardy; the latter went to Europe in early May and started to work for the RILU. In June 1922, the British Bureau of the ITUC/RILU (existing since December 1920) and the National Workers' Committee Movement were merged and were since then known as the (National) Minority Movement or M M. ${ }^{23}$ In late October 1922, Mussolini and the fascists took control over Italy and unleashed a terror campaign against the Italian labour movement. Among the affected ones was the Italian maritime workers' union or Federazione Italiana dei Lavoratori del Mare (FILM). Organisational matters where therefore high on the agenda when the RILU summoned for its Second World Congress in Moscow in November 1922. In conjunction with the RILU Congress, the IPCTw organised a conference to boost its activities. The outcome was a new push into Western Europe.

\subsection{The Hamburg Connection}

The Hamburg Port Bureau in Hamburg was the first maritime unit of the IPC-TW set up outside Soviet Russia. Projected to start operations in late 1921, its opening was delayed for a year. Although the bureau was officially set up on 29 December 1922, ${ }^{24}$ effective operative work started two months later. ${ }^{25}$ The position of bureau within the RILU-apparatus became a model for the other Port Bureaus established during the 1920s. Headed by Albert Walter, the Hamburg Port Bureau was institutionally and organisationally separated from the Schiffahrtsbund although both organisations had their offices at 8 , Rothesoodstrasse in a building acquired by Walter to serve for this purpose. Instead of using the logotype and symbols of the Schiffahrtsbund, the Central European Bureau of the RILU in Berlin (RILU Berlin Bureau) instructed Walter to create separate ones for the Port Bureau and to establish contacts with RILU-affiliated units as well as with minority and opposition groups within the maritime unions. Further, the RILU Berlin Bureau instructed Walter to send them monthly activity reports as well as copies of all correspondence. ${ }^{26}$ In spring 1923, some Dutch activists started another Port Bureau in Rotterdam

22 See further Peter Cole, "Strange Bedfellows but Not for Long: The Industrial Workers of the World and the Communist International," in The Internationalization of the Labour Question: Ideological Antagonism, Workers' Movements and the ILO since 1919, eds. Stefano Bellucci and Holger Weiss (London and New York: Palgrave MacMillan, 2020), 259-278.

23 Tosstorff, The Red International of Labour Unions, 276-277, 463.

24 Hamburg Hafenbüro to MEB, 7.4.1923, 534/5/157, 3-4, RGASPI.

25 Report re Bürositzung vom 22. Mai 1923, 534/5/157, 19-20, RGASPI.

26 Reinhardt/MEB RGi to Internat. Hafenbüro Hamburg, Berlin 13.3.1923, 534/4/52, 73-78bp, RGASPI. 
and the RILU Berlin Bureau ordered the new unit to establish contacts with the Hamburg Port Bureau. ${ }^{27}$

The Hamburg Port Bureau was at the lower end within the internal hierarchy of the RILU apparatus. The Port Bureau was subordinate to the RILU Berlin Bureau, which, in turn, ranked below the IPC-TW and RILU secretariats in Moscow. Consequently, Berlin rather than Hamburg was the operational node of the IPC-TW in Western and Northern Europe. ${ }^{28}$ This hierarchical structure was evident already in March 1923. At this point, Reinhardt at the RILU Berlin Bureau informed Walter that he had forwarded a letter from the Finnish Seamen's Union originally received by the Hamburg Bureau to the headquarters in Moscow; the letter was about a planned seamen's strike and the Berlin Bureau together with the comrades in Moscow were to decide about appropriate actions. ${ }^{29}$ On the other hand, when the RILU Berlin Bureau received letters from foreign seamen's organisations, it would send copies to the Port Bureaus and order them to establish contacts with the sender. For example, this was the case when Reinhardt informed the IPC-TW secretariat in Moscow that he had forwarded a letter from the Marine Transport Workers Industrial Union in New York to the Port Bureaus in Hamburg and Rotterdam in March 1923. ${ }^{30}$

Initially, Walter and the Swede A. J. Smålan ${ }^{31}$ were running the daily operations of the Hamburg Port Bureau. Their main task, it seems, was to establish the Port Bureau as the global relay station for the IPC-TW's outreach to maritime unions. To achieve this goal, Walter and Smålan immediately sent letters to the maritime unions in Australia, China, Denmark, Finland, Norway and Sweden, as well as to contact persons in Britain, France, and the United States. ${ }^{32}$ Also, they furnished a reading room at the premises of the Port Bureau and were soon to able to attract 50 visitors daily, mostly crew members from US American, British, Finnish and German vessels. ${ }^{33}$ Still, two major hurdles restricted the operational capacities of the Port Bureau. One concerned logistics: The Port Bureau did not have a motorboat at its disposal and its functionaries could only cover a small part of the extensive harbour area. The second

27 MEG to Rotterdamer Hafenbüro, no date [ca April 1923], 534/4/52, 95, RGASPI.

28 Reinhardt to IPC-TW Moscow, Berlin 13.3.1923, 534/4/52, 79, RGASPI.

29 Reinhardt/MEB RGI to Internat. Hafenbüro Hamburg, Berlin 12.3.1923, 534/4/52, 73-74, RGASPI.

30 Reinhardt to IPC-TW Moscow, Berlin 14.3.1929, 534/4/52, 80, RGASPI.

31 Smålan was the pseudonym of Swedish journalist Nils Albert Johansson (1888-1965). See https://sv.wikipedia.org/wiki/A.J._Sm $\% \mathrm{C}_{3} \%$ A5lan. His name is spelled Smolan in contemporary documents.

32 Hamburg Hafenbüro to MEB, 7.4.1923, 534/5/157, 3-4, RGASPI.

33 Report re Bürositzung vom 22. Mai 1923, 534/5/157, 19-20, RGASPI. 
concerned languages: The Port Bureau lacked a member fluent in English. Consequently, agitation on board US American and British vessels was limited. ${ }^{34}$ At least the second hurdle was soon overcome and in early July, Smålan informed about the formation of a "Union for Oriental Seamen" in Hamburg. However, he himself was ambiguous if the association was a success or not; in fact, it seems as if Smålan had not much information about it. ${ }^{35}$

Nevertheless, the members of the Port Bureau made a virtue out of the constraints and directed their main energy on agitating among Scandinavian seamen. At this point, there were high hopes in Moscow for at least the Swedish Seamen's Union to affiliate with the RILU, and Walter received order to participate at the federation meeting of the Swedish union in April $1923 .{ }^{36}$ It is doubtful if Walter's visit in Sweden made any impact as the Swedish union never affiliated to the RILU. Back in Hamburg, Walter received orders from RILU General Secretary Lozovsky to concentrate on the Schiffahrtsbund whereas Smålan was nominated as interim secretary of the Port Bureau. ${ }^{37}$

\subsection{Preparing the Ground in Britain and the USA}

The United Kingdom was another key area for communist agitation and propaganda among maritime workers. The British merchant fleet was the largest in the world. Its crew constituted of white and non-white mariners, the latter ones being mainly of Indian, Chinese, Arab and African origin. The dominant union was National Sailors' and Firemen's Union or NSFU, and the ambition of the IPC-TW was to unify the radical elements within the union. The key instigator for this policy was George Hardy who arrived in London in late December 1922. Hardy, who at this point used the pseudonym Geo Hall, had been mandated by the IPC-TW to establish its operational basis in Britain and aspired to set up committees in the various ports and, ultimately, to establish Port Bureaus. The RILU British Bureau instructed him to co-operate with Fred Thompson, party member and important official of the Transport and General Workers Union, to accomplish his mission. Hardy set off for a tour in the United Kingdom and constituted committees in Glasgow, Liverpool, London and Southampton. In London, he organised meetings in Poplar Town Hall during mid- and late January 1923; one thousand seamen, Hardy claimed in his report to the ITCTw headquarters, attended the latter. Fred Thompson was elected as chair and

34 Hamburg Hafenbüro to ME B, 7.4.1923, 534/5/157, 3-4, RGASPI.

35 Secretary/Int. Seamen's Bureau in Hamburg to мЕв, Hamburg 7.7.1923, 534/5/157, 33-34, RGASPI.

36 Reinhardt to Hamburg, 26.3., 5.4., 13.4., 16.4.1923, 534/4/52, 85-87, 89-94, RGASPI.

37 Report re Bürositzung vom 22. Mai 1923, 534/5/157, 19-20, RGASPI. 
Fred Potter nominated secretary at a subsequent meeting of the committees. Hardy instructed the committees to be in touch with the Hamburg Port Bureau and urged Potter to send monthly reports to the RILU Bureau in Berlin. Having thus laid the operational basis for work among maritime workers in the United Kingdom, Hardy rushed to the United States. ${ }^{38}$

Hardy had a rather realistic perspective on the possibilities of successful work in Britain. "Port Bureaus cannot be set up yet, but London will be the place for such an opening when conditions warrant," he informed headquarters in Moscow, and noted that "objective" conditions for institutionalised work were challenging. ${ }^{39}$ Similar constraints prevailed in the USA where the communist minority within the IWw was marginalised. Still, he notified the Russian Bolshevik Mikhail Kalinin about his plans to organise a Port Bureau or at least a committee in New York whereupon he would to comply with RILU instructions and relocate to Hamburg.40

\section{The 1923 Berlin Conference and Its Aftermath}

Socialist-controlled labour unions as well as the ITFU were highly suspicious about communist agitation throughout 1922. A critical point was the positions of those unions who had joined the RILU, including all Russian ones: Could they also be members of an International Trade Secretariat? In April 1922, the IFTU Congress in Rome decided against double-membership: Only IFTU member unions could join the International Trade Secretariats. This decision nullified the achievements of most International Propaganda Committees. However, the International Transport Workers' Federation seemed at first to be an exception. Influential members among its leadership, including ITF Secretary Edo Fimmen, were left-leaning and open to negotiations with representatives of the Russian trade unions. These positive conditions culminated in spring 1923 when Fimmen agreed on behalf of the ITF - but without permission of the IFTU - to a conference with the Russian transport workers on the danger of war and fascism in May in Berlin. ${ }^{41}$ As an outcome, the Berlin

38 Geo Hall [George Hardy] to Secretariat IPC-TW of the RILU, Liverpool, no date [ca February/1922], 534/5/155, 84-90, RGASPI.

39 Geo Hall [George Hardy] to Secretariat IPC-TW of the RILU, Liverpool, no date [ca February/1922], 534/5/155, 84-90, RGASPI.

40 G.H. [Georg Hardy] to Comrade Kalinin, Chicago 8.4.1923, 534/5/155, 79-8o, RGASPI.

41 See further Kasper Braskén, "Making Anti-Fascism Transnational: The Origins of Communist and Socialist Articulations of Resistance in Europe, 1923-1924," Contemporary European History 25, no. 4 (2016), 584. 
Conference decided to establish a joint action committee to direct a campaign against war and fascism. Most importantly from Moscow's perspective was the plan to organise a unity congress of the IFTU and RILU in autumn $1923 .{ }^{42}$ From Moscow's perspective, the call for a unity congress framed the communist trade union doctrine of the United Front for reconciling the organised labour movement. ${ }^{43}$ However, negotiations halted when Fimmen informed the IFTU's bureau in Amsterdam and after vehement opposition from the ADGB, among others, the IFTU terminated its engagement. ${ }^{44}$

\subsection{Framing the Activities of the Port Bureaus}

A resolution adopted by the Third Session of the General Council of the RILU, held in Moscow 25 June - 2 July 1923, framed the work among maritime transport workers. The resolution outlined the strategic and tactical objectives for communist agitation and propaganda among seamen. Firstly, the resolution inculcated the revolutionary transport workers' unions, the revolutionary minorities as well as the Port Bureaus to execute the decisions of the 1923 Berlin Conference regarding the United Front as well as the struggle against fascism. Secondly, the key units for the dissemination of revolutionary propaganda among the seamen were the Port Bureaus in and outside Soviet Russia. The resolution instructed the Executive Bureau of the RILU to accelerate its publication of class-conscious seamen's literature in all European and Eastern languages. In addition, the RILU ordered the IPC-TW to furnish the Port Bureaus with publications for the popularisation of the communist perspective on the United Front. ${ }^{45}$

Most importantly, the resolution requested the IPC-TW to draft a program of action to address the specific conditions of the seamen's life, afloat and ashore, to attract unorganised maritime workers into the revolutionary opposition as well as to intervene in and utilise conflicts arising on foreign ships in the ports. The rationale was to issue instructions to the revolutionary opposition groups and to the Port Bureaus for the intervention to protect the interests of seamen and to settle conflicts between the seamen. The RILU also instructed

42 "Report by Comrade Lozovsky on the Trade Union Question," Inprecor 3: no. 49 (12 July 1923): 495-496.

43 For a detailed description and analysis, see further Tosstorff, The Red International of Labour Unions.

44 Braskén, "Making Anti-Fascism Transnational," 584.

45 Port Bureaus and the Activities among Seamen, no date [ca. 1923], 534/2/11, 100, RGASPI. Fort he published version of the text, see "The Harbour Bureaus and Work among Seamen," Inprecor 3: no. 65 (6 October 1923): 726. 
the IPC-TW Secretariat to collect quantitative data on wages and working conditions of seamen, formulate tactics and methods of the struggle for better working conditions, and issue corresponding instructions to the revolutionary opposition groups as well as to the Port Bureaus. ${ }^{46}$

In conformity to the decisions of the 1923 Berlin Conference, the RILU charged the revolutionary opposition groups and Port Bureaus to establish control committees to monitor the transportation of war materials. Apart from this, the RILU instructed them to adapt the struggle against fascism to local conditions and closely co-operate with all other local and national revolutionary labour organisations in this fight. ${ }^{47}$

Apart from United Front and anti-war/anti-fascism activities, the RILU impelled the IPC-TW and the Port Bureaus to highlight the condition of the unemployed seamen. Here, the key idea was the formation of so-called unemployed committees in every port; "these Committees shall have the task of conferring with ships' crews, and to see to it that the hiring of seamen is done only thru the Employment Bureaus," the resolution declared. Besides, concerning strike tactics, the revolutionary unions and the Port Bureaus received instructions to combat strikebreaking and disorganisation as well as to create an international seamen's fund for mutual aid as to assist unemployed seamen in every port. Last, but not least, the Port Bureaus received instructions to extend their activities to the railroad workers and the local transport workers, "wherever there exists no local transport or railroad workers' bodies carrying on revolutionary activities along the lines of the Transport Workers' IPC or of the revolutionary unions." ${ }^{48}$

\subsection{The Interlude of Geo Hall}

The IPC-TW headquarters decided sometimes in early spring 1923 to transfer George Hardy as secretary of the Hamburg Port Bureau. Probably residing at this point in the United States, he received a confirmation of the plan, moved across the Atlantic and settled in Hamburg using his nom de guerre Geo Hall on 12 July $1923 .{ }^{49} \mathrm{He}$ found working conditions at Rothesoodstrasse to be

46 Port Bureaus and the Activities among Seamen, no date [ca. 1923], 534/2/11, 100, RGASPI.

47 Port Bureaus and the Activities among Seamen, no date [ca. 1923], 534/2/11, 100, RGASPI.

48 Port Bureaus and the Activities among Seamen, no date [ca. 1923], 534/2/11, 101, RGASPI.

49 Hardy's use of his pseudonym varied and depended on the context of his appearance. He used his own name when commenting British affairs but his pseudonym when making official statements as secretary of the Hamburg Port Bureau. See, for example, Geo Hardy, "The Strike of the British Dock Workers," Inprecor 3, no. 55 (9 August 1923): 591-592, and George Hall, "Seamen and United Front," Inprecor 3, no. 55 (9 August 1923): 590-591. 
pathetic if not chaotic as Smålan had left the bureau about one month earlier "without completing all arrangements." Therefore, Hardy's priority was to (re-)establish the international network and connections of the Hamburg Port Bureau and to design an international action program for seamen. ${ }^{50}$ Already within the next month, he received letters and notifications from the Industrial and Commercial Workers' Union, a non-white union in South Africa, the Hong Kong and Shanghai sections of Chinese Seamen's Union, and the Marine Transport Workers' Industrial Union in the USA. ${ }^{51} \mathrm{He}$ appealed (in vain) to the latter for affiliating with the "Revolutionary Transport Workers of the RILU." ${ }^{2}$ By the end of September, his international network had expanded further and he had established connections with the British Colombia Seafarer's Federation in Canada, the Danish Stokers' Union (Søfyrbødernes forbund), the Amalgamated Marine Workers' Union of Great Britain and the Irish Transport Workers' Union. 53

Hardy was no doubt a visible agitator in Hamburg. At the end of July, he boasted of having organised the "first international mass meeting for seamen" at Wulff's Gesellschaftshaus in Altona adjacent to Hamburg, with more than 800 seamen attending. ${ }^{4}$ Two months later, he organised a protest meeting against the Italian occupation of Corfu ("700-80o attending") as well as a second mass meeting at Wulff's Gesellschaftshaus to propagate for the formation of "Committees of Action." 55

Hardy's main objective was to push for the amalgamation of the Schiffahrtsbund with the German Transport Workers' Federation (Deutscher Transportarbeiter-Verband, from 1923 Deutscher Verkehrsbund) as part of the United Front-tactics. Hardy's main ally was Albert Walter who backed the idea

5O Geo Hall to IPC-TW, Hamburg 24.8.1923, 534/5/157, 48-49, RGASPI. Smålan had moved to Berlin where he worked for the Internationale Gewerkschaft-Pressekorrespondenz.

$5^{1}$ Report of Comrade Hardy for July the 12th to August 31st, Hamburg 31.8.1923, 534/5/157, $53-58$, RGASPI.

52 Hall to General Convention of the Marine Transport Workers Industrial Union, Hamburg 13.9.1923, 534/5/157, 68-71, RGASPI. Unfortunately, I have not been able to trace his correspondence with the other organisations but I assume that it contained a similar message. Geo Hall, Report for September 1923, 534/5/157, 99-102, RGASPI.

54 Geo Hall to RILU Executive Council, Hamburg 27.7.1923, 534/5/157, 37, RGASPI. Echoing the decisions of the Berlin Conference, the meeting supported the vision of an international united front of all transport workers and urged the ITF and RILU to summon a joint conference "as soon as possible." See George Hall, "Seamen and United Front," Inprecor 3, no. 55 (9 August 1923): 590-591.

55 Geo Hall, Report for September 1923, 534/5/157, 99-102, RGASPI. The call for the creation of Action Committees of the maritime workers was published as "International Seamen against War," Inprecor 3, no. 61 (20 September 1923): 681. 
as the Schiffahrtsbund had lost most of its influence - the organisation counted some 21,000 members during its heydays but only 4,000 in 1923. Tactically and strategically, the fusion of the two unions was top priority; not least, as the merger of a lesser communist-controlled organisation with a bigger socialist/ social democratic-controlled organisation would enable communist agitation and propaganda within the union and, by extension, the IT F. ${ }^{56}$

Hardy's activities in Hamburg were paying off. The relations with the RILU Bureau in Berlin were smooth and Moscow funded the Hamburg Port Bureau through monthly instalments via Berlin. ${ }^{57}$ By the end of September, he had published a pamphlet, An Appeal to the Toilers of the Marine Industry, ${ }^{58}$ an antiwar leaflet with 7,00o copies in English and 5,000 copies in German, and was just about to publish the first issue of the International Seamen's Bulletin. ${ }^{59}$

\subsection{Setback? The German October and Its Consequences}

George Hardy's reports to the comrades in Berlin gives the impression that the Hamburg Port Bureau was completely unaffected by the societal turmoil in Germany during 1923. One looks in vain for any hits about the deteriorating economic and political conditions that marked the year - the economic crisis as well as the occupation of the Ruhr area by French and Belgian troops in January 1923, followed by the general strike of the workers in the Ruhr area. Neither are there any comments on the violent clashes between left- and right-wing elements and paramilitary units, culminating in the nationwide strikes against the government. On the other hand, this does not imply that the Hamburg Port Bureau did not respond to the situation in Germany. When German seamen demanded for international wages to be paid in gold and went on strike in June, the Hamburg Port Bureau published at least one appeal for international solidarity actions in support of 1,200 striking German seamen in Britain. ${ }^{60}$ In addition, it sent instructions for legal and illegal activities among transport workers to counteract an international intervention in Germany in the aftermath of the Ruhr occupation. ${ }^{61}$

\footnotetext{
56 Geo Hall to ME B, Hamburg 10.9.1923, 534/5/157, 65-66, RGASPI.

57 Geo Hall to Max Ziese/мев, Hamburg 20.9.1923, 534/5/157, 78-79, RGASPI.

$5^{8}$ George Hall, An Appeal to the Toilers of the Marine Industry, no date [ca. 1923], 534/5/157, 83, RGASPI.

59 Geo Hall, Report for September 1923, 534/5/157, 99-102, RGASPI.

6o Apell: An die Seeleute aller Länder. Internationale Unterstützungsaktion zu Gunsten der streikenden deutschen Seeleuten, 534/5/155, 72-75, RGASPI. It is likely that the original text was written in Hamburg and transferred to Berlin where it was translated and published as A.J. Smolan, "The German Seamen's Strike," Inprecor 3, no. 50 (12 July 1923): 517. Copy of memorandum, no date [ca. 1923], 534/5/155, 91-92, RGASPI.
} 
The situation remained tense in Germany throughout the year. At the end of September, the government declared a state of emergency. On 1 October, right-wing paramilitary troops in Küstrin attempted a putsch. Two weeks later, the German parliament adopted an enabling act that was to facilitate a de jure dictatorship by Chancellor Gustav Stresemann. Large-scale demonstrations followed in Berlin. In Saxony and Thuringia, coalition governments were formed which included the German Communist Party (KPD). The communists held divergent interpretations of the 'signs of the hour'. Leading members of the Soviet Politbureau as well as the Comintern and its emissaries in Germany advanced the idea of an armed rebellion; others, including KPD leader Heinrich Brandler, were against it as they felt that conditions for a revolution in Germany did not yet exist. An intensive debate followed behind the curtains about what actions to be taken. Eventually, the party leadership called the uprisings off. For reasons still unclear, all other party sections apart from the KPD Wasserkante in the Hamburg region followed orders. Here, the local military leader of the party received orders of the regional party leadership to start the rebellion on 22 October 1923. The attempt proved futile and police forces crushed the uprising within the next day. For the social democrats, the uprising confirmed the rumours of a hidden agenda of the communists: Officially working through parliamentary politics but de facto aiming for a Bolshevik Revolution. If the relationship between the Left and the ultra-Left had been sour before the German October, the failed uprising split the German Left into two fighting blocks. Poisoned as it was already before October 1923, the rift of the German labour movement was to affect the relationship between the socialist and communist blocks on a global level. ${ }^{62}$

The turmoil in Hamburg cut Hardy's links to the RILU Berlin Bureau. Although the Hamburg Port Bureau was not directly involved in the uprising, it is likely that its operations came to a standstill. Hardy and Walter appear not to have been engaged in the planning of the uprising as they had visited Rotterdam and Amsterdam on 18 and 22 October; perhaps they were not even present in Hamburg on 23 October. Working conditions deteriorated after the failed uprising. The authorities in Hamburg declared martial law, and the police raided the premises of the Port Bureau on 24 October and 24 November. The Hamburg authorities outlawed all organised activities of the communists, including those of the Port Bureau. The illegality of the bureau effectively curtailed its activities in the harbour area. Consequently, the functionaries of the

62 Bernhard H. Bayerlein et al. (eds.), Deutscher Oktober 1923. Ein Revolutionsplan und sein Scheitern (Berlin: Aufbau-Verlag, 2003). 
Port Bureau turned to clandestine methods and started to approach foreign mariners at cafés and bars. Nevertheless, Hardy and his team managed to edit and send the second issue of the Port Bureau's journal, The International Seafarer, to the RILU Berlin Bureau for printing. ${ }^{63}$ On 24 November 1923, German authorities banned the KPD and suppressed all Communist organisations and units, including the Berlin Bureau of the RILU. The existence of the Hamburg Port Bureau was doomed. Hardy returned to England at the end of $1923 \cdot{ }^{64}$

Summarising his experiences of illegal and "semi-illegal" work in Hamburg, Hardy pushed for moving the international centre for agitation and propaganda among seamen to London. Communist activity had been banned throughout Germany. Moving the IPC-TW seamen's section to another country would be preferable, he argued, instead of facing the constant harassment by police and port authorities. Printing costs were high due to inflation and the uprising had cut contacts with the party. Most importantly, Hamburg was not an ideal place to work among foreign mariners as the bulk of them called at British ports. Besides, it was absolute necessary to conduct work in the English language. "Unless we can get the support of the British seafarers we cannot have a truly seamen's organisation," Hardy stressed. Therefore, moving the headquarters to London would ignite the British comrades to speed up their activities that so far had slumbered. 65

However, Hardy's proposal of shifting the centre of gravity from Hamburg to London did not materialise. Instead, the RILU Berlin Bureau instructed the Rotterdam Port Bureau to start agitation and propaganda work among British seamen. ${ }^{66}$ In March 1924, the German authorities lifted the ban on communist activities and work could resume in the port of Hamburg. About one month later, a certain comrade Alex send a handwritten message to Berlin: The Hamburg Port Bureau had resumed its operations. ${ }^{67}$ Alex, whom I have not been able to identify, must have been an instructor of the IPC-TW who had been sent to Hamburg to re-establish the Port Bureau. Work in the Hamburg harbour recommenced and by early May Alex' team was again visiting US

63 Geo Hall, Report October + November 1923, 534/5/157, 111-116, RGASPI.

64 Home Office Warrant, 1.3.1924, George Hardy personal file, KV 2/1027, 17A, TNA; J. Bell to Sir Vernon Kell, Record re George Hardy, 12.1.1932, George Hardy personal file, KV 2/1027, 66b, TnA; George Hardy, Those Stormy Years: Memoirs of the Fight for Freedom on Five Continents (London: Lawrence \& Wishart, 1956), 168, 170-171, 177.

65 Geo Hall, Report October + November 1923, 534/5/157, 111-116, RGASPI.

66 мев to Port Bureau Rotterdam, Berlin 4.1.1924, 534/4/89, 1, RGASPI.

67 Handwritten message from 'Alex' to 'Genosse Paul', no date [ca. April 1924], 534/5/164, 14, RGASPI. Paul was the pseudonym of Max Ziese who was head of the RILU Berlin Bureau. 
American and British ships. Most importantly, the bureau office had moved back into its old location at Rothesoodstrasse. ${ }^{68}$ At this point, the IPC-TW had two nodes for legally disseminating literature in English, including its mouthpiece The International Seafarer: Hamburg and Rotterdam. ${ }^{69}$

\subsection{A Missed Opportunity in Sydney}

Left-wing syndicalism was salient among the maritime transport workers in early twentieth-century Australia. The seamen and their union, the Seamen's Union of Australia (SUA), established in 1906, stood at the frontline of activities. $^{70}$ Before and during the war, Iww-adherents or Wobblies, such as Tom Barker and William (Bill) Casey, and their supporters dominated among the radical members of the SUA in Sydney. Both were actively engaged in the anticonscription campaign during the war, and Casey had made a name of himself as a master of satire and political propaganda, not least by his Iww song 'Bump Me Into Parliament'. While the Australian authorities had expelled Barker in 1918, Casey became involved in the 1919 seamen's strike. ${ }^{71}$

The 1919 Australian seamen's strike was a watershed for the infusion of communism among the members of the seamen's union. In 1918, Tom Walsh (18711943), socialist and key propagator of revolutionary left, was elected as secretary of the sUA. One year later, he led a three-month strike that brought most shipping to a halt, resulting in a closure of many factories in Australia. Key demands were increased rates of pay, reduced working-hours, better accommodations on ships and insurance against death. Starting in Queensland in May, the strike soon spread to Victoria and New South Wales and eventually to all states of Australia. Pickets were being maintained at docks, which effectively hindered the use of scab labour. Soon the strike was felt outside the harbours thousands of workers of manufacturing industries had to be stood down, coal supplies were held up and power restrictions had to be implemented. Walsh was jailed when he rejected to attend arbitration but this had little effect on the

68 Alex to Paul, Hamburg 4.5.1924, 534/5/164, 24, RGASPI.

69 мЕ в to Port Bureau Hamburg, Berlin 17.4.1924, 534/4/89, 3, RGASPI.

70 Organised union activity had started in Australia in 1874 with the establishment of the Sydney Seamen's Union and the Melbourne Seamen's Union. In 189o, the two organisations formed a loose federation known as the Federated Seamen's Union of Australasia, renamed in 1906 as the Seamen's Union of Australia. See further Brian Fitzpatrick and Rowan J. Cahill, The Seamen's Union of Australia 1872-1972 (Sydney: Seamen's Union of Australia, 1981), and Diane Fitzpatrick, Voices from the Ships: Australia's Seafarer's and their Union (Sydney: University of New South Wales Press, 2008).

71 Verity Burgmann, Revolutionary Industrial Unionism: The Industrial Workers of the World in Australia (Cambridge: Cambridge University Press, 1995), 66. 
strikers. Eventually, after three months, the Australian government was forced to negotiate with the union outside the arbitration system. The government had to give in: The workers received an increase of 35 shillings per month, the 8-hour working day was recognised and the seamen received better accommodation and sick pay. Walsh was released from jail in September. ${ }^{72}$

The communist fraction within the SUA gained prominence as an outcome of the victorious strike. Casey joined in and was sent, together with another exWobbly Barney Kelley, to Moscow in 1921 as delegates of the Seamen's Union at the International Trade Union Congress and the subsequent conference of transport workers. ${ }^{73}$

Back at home, left-wing radicals dominated the sUA. At the time of the formation of the Communist Party of Australia (CPA), the Seamen's Union, and especially its leader Tom Walsh, played an important role in organising the party. Soon, however, both the Seamen's Union and the CPA entered muddy terrain when they tried to apply the United Front-tactics at home. The radical elements within the union, among others Casey, discharged the communist invitations towards the Australian Labour Party as a deviation from outright revolutionary politics and tactics. The effects were disastrous for the communists and many seamen left the $\mathrm{CPA} .{ }^{74}$

The ideological clashes within the party and the union culminated during the maritime transport workers strike in North Queensland in 1923. Tom Walsh and others were attacked on the management of the strike. The confrontations shattered the foundations of the party; most unionists left the party while the Seamen's Union was split into factionalism. The crisis culminated in 1924 when the leading members of the Seamen's Union, including Casey, formed the Socialist Party of Australia. ${ }^{75}$

The complex situation on the Australian waterfront proved a challenge for the RILU and the IPC-TW. Hopes were raised for the establishment of a Port Bureau in Sydney in 1921 but nothing came out of it. Direct communication with the comrades in Australia proved difficult, not to speak about directing

72 "History: The 1919 seamen's strike," The Socialist. Magazine of Socialist Action in Australia, 20.5.2019, http://socialiststandardmyspace.blogspot.com/2013/12/obituarybill-casey-socialist-pioneer.html (checked 27.1.2020).

"Orbituary: Bill Casey - Socialist Pioneer," The Western Socialist, November-December 1949, republished 12.12.2013 at http://socialiststandardmyspace.blogspot.com/2013/12/ obituary-bill-casey-socialist-pioneer.html (checked 27.1.2020).

74 Frank Farrell, International Socialism and the Australian Labour. A Study of the impact of left-wing and internationalist doctrines and influences on the organised labour movement, 1918-32, PhD thesis, Australian National University, 1975, 92-93.

Farrell, International Socialism and the Australian Labour, 93. 
and monitoring affairs in the Seamen's Union. A new attempt to bring order within the union, to pave the way for a Port Bureau and the opening of an Interclub in Sydney, was made in 1924 when George Hardy was sent to Australia as an emissary of the RILU. Hardy's mission was unsuccessful. The Seamen's Union proved incapable of organising a Port Bureau. Four years later the RILU sent another emissary to Australia. One result of his visit was the establishment of the Sydney Port Bureau and Interclub. ${ }^{76}$

76 Farrell, International Socialism and the Australian Labour, $158 \mathrm{fn}$ 123. Farrell states that "Hardy or some other prominent British RILU emissary" was sent to Australia. Although Hardy's visit to Australia is not confirmed, he could have made the trip after he returned to Britain in late 1923/early 1924. However, there is no information on such a visit in his Special Branch/MI5 dossier, KV 2/1027, TNA. 